\title{
Educational tourism and nation building: Cross-border school trips in the Carpathian Basin
}

\author{
TAMARA RÁTZ ${ }^{1}$, GÁbor MICHALKÓ² and RÉKA KESZEG ${ }^{3}$
}

\begin{abstract}
Educational travel provides opportunities for participants to explore specific issues in unconventional ways. In Hungary, primary and secondary schools organise annual study trips as part of their curricula. The aim of these trips is to familiarise students with the main sights of the country, and to bring to life national narratives discussed in lessons. Furthermore, these trips often play a key role in students' socio-psychological development, both as future tourism consumers and as future citizens. Recognising the opportunity to influence students' worldview and way of thinking during their sensitive teenage years, the Hungarian government has created a national programme to financially support school trips organised to visit minority Hungarian communities living in the neighbouring countries. This paper is based on the content analysis of 256 detailed reports submitted by participants of school trips organised in 2013/14 with the aim to visit Hungarian minority communities in the Carpathian Basin. The analysis focuses on the detailed descriptions of the participants' personal memories of their experiences, the social construction of the visited destinations, and the influence of their memorable experiences on their sense of national identity. The research disclosed that the trips made to Hungarian territories outside the borders contributed to shaping the national sentiment of the students participating in the programme. The findings suggest that since participation in tourism is an effective means to experience nationhood and national identity, by financially supporting school trips abroad, the state may be able to exert political influence over national consciousness.
\end{abstract}

Keywords: ethnic tourism, educational trip, national identity, nation building, Carpathian Basin, Hungary, 'Without Borders!' project

\section{Introduction}

In the past decades, researchers have revealed several aspects of the symbiosis of tourism and politics (e.g. Burns, P. and Novelli, M. 2007). Most of the monographic work was economics- (Mosedale, J. 2011), controlling(Pender, L. and Sharpley, R. 2005) and development-oriented (BRIEN, A. 2011), while among social approaches, several publications have dealt with the role of the state in social tourism (e.g. LA PlacA, V. and Corlyon, J. 2014) or the relationship of travel and national identity (BHANDARI, K. 2014).
Generating and maintaining nationalism with the help of tourism occurs in domestic and in international tourism as well (PRETES, M. 2003). Through the development of the tourism industry after World War 2, both democratic and totalitarian states - with diverse motivations - took part in encouraging trips with the objective to strengthen national identity (Palmer, C. 1999). The establishment and expansion of the European Union, on the one hand, have gradually contributed to stronger national identities (McLaren, L. 2004), while, on the other hand, have facilitated unrestricted border crossings, based on the

\footnotetext{
${ }^{1}$ Kodolányi János University, 1139 Budapest, Frangepán u. 50-56. Hungary. E-mail: tratz@kodolanyi.hu

${ }^{2}$ Geographical Institute, Research Centre for Astronomy and Earth Sciences, 1112 Budapest, Budaörsi út 45; Corvinus University of Budapest, 1093 Budapest, Fővám tér 8. Hungary. E-mail: michalko.gabor@csfk.mta.hu

${ }^{3}$ Budapest Marriott Hotel, 1052 Budapest, Apáczai Csere János utca 4. Hungary. E-mail: keszeg.reka@gmail.com
} 
principle of the free movement of persons laid down in the Treaty of Rome. The integration of East Central Europe to the European Union revealed the suppressed dreams of countries in the Carpathian Basin concentrating on strengthening national identity (Young, C. and Light, D. 2001). What was unimaginable in the former socialist camp strictly controlled by the Soviet Union came true in the European Union. The EU's minority policy supports the establishment of cultural connections between minority groups and their motherland in many ways, which also opened the gates to political initiatives strengthening national identity in neighbouring countries under the auspices of cultural cooperation (SASSE, G. 2008). Tourism represents one aspect of mobility among euro-regions, in the framework of which - through the development of cultural and heritage attractions - many trips are realized with the motivation of nation-building.

Similarly, there is a growing body of literature focusing on the role and benefits of educational travel, partly as a means of connecting the theoretical world of academia with the realities of tourist destinations (TARRANT, M.A. et al. 2011) and to encourage critical reflection on behalf of the students (BoLuK, K. and CARnicelli, S. 2015), partly as initiatives embracing the principles of experiential learning in the forms of study trips and field schools (LiAnG, K. et al. 2015). However, most authors concentrate either on university students (particularly on medium- and longterm study abroad programmes) (e.g. Juvan, E. and Lesjak, M. 2011; Abubakar, M. et al. 2014), and on the role of field visits in travel \& tourism, or tourism \& hospitality degree programmes (e.g. SANDERs, D. and Armstrong, E.K. 2008; Arcodia, C. and Dickson, C. 2013), or on adults participating in educational experiences as a form of lifelong learning or as serious leisure (e.g. Pitman, T. et al. 2010; KAsK, S. 2011), and there is a general gap in the literature when it comes to elementary or secondary schools' activities.

The present study tries to fill this gap by analysing a Hungarian governmental programme that aims to strengthen adolescents's national identity in the context of educational travel. In addition, it also proposes to contribute to the widening discussion on the relationship of tourism and politics, with special consideration to using tourism as a means to achieve political goals. The objective of the study is to discuss, using an exploratory approach, the phenomenon of financially supported school trips organised outside the borders with the motivation of reinforcing national identity. The paper reviews the historical and political antecedents of national identity building, presents the tourism aspects of the 'Without Borders!' programme, identifies the spatial and temporal characteristics of the trips carried out during the 2013/2014 school year, as well as evaluates the experiences of the student participants during these trips, with special emphasis on national identity, and the social, community-building role of travel. Based on content analysis of the participating students' reports, the primary objective of the study is to determine whether the government's intention to use travel as a means to national identity building is fulfilled with the 'Without Borders!' programme.

\section{Theoretical background}

\section{National identity in the Carpathian Basin - the} geopolitical context

Hungary occupies a special place in the processes of national identity building in the Carpathian Basin. According to the Trianon Peace Treaty signed in 1920, following World War 1, two-thirds of the territory of former historical Hungary, and half of its population were allocated to the neighbouring countries, leaving approximately 3 million ethnic Hungarians outside the new borders (Kovács, Z . 1989; Kocsis, K. and Kocsis-Hodosi, E. 1998). The Trianon Peace Treaty caused a trauma in the Hungarian society, a deeply rooted feeling of injustice that proved difficult to cope with and resulted in serious political consequences (GERnER, K. 2007). Among oth- 
ers, the rising of nationalism and revisionism led Hungary to participate in World War 2 as an ally of Nazi Germany, and the defeat brought about another downfall. The Paris Peace Treaties signed in 1947 restored Hungary's borders, with a minimal modification, as laid down in the Trianon Peace Treaty.

Between 1947 and 1989, Hungary was a oneparty dictatorial socialist state under the influence of the Soviet Union. After 1947, there was no place for condemning the Trianon Peace Treaty or the Paris Peace Treaties, the police of the Communist-Socialist party repressed systematically all nostalgic feelings about the greatness of former historical Hungary. In the Eastern Block controlled by the Soviet Union the notion of internationalism was promoted, preventing by all means possible the emergence of national identities. The regions located along state borders, which symbolized national identity, were deliberately underdeveloped, transforming them both economically and socially into peripheries (Erôss, Á. and TÁtrai, P. 2010). Throughout the decades, the neighbouring states, despite proclaiming the ideology of peaceful coexistence, were trying to impede cross-border relationships, even between families and relatives. This was achieved not only by making crossing borders more difficult, but also by relocating ethnic minorities living along the frontiers across the country.

The fate of millions of Hungarian minorities trapped outside the motherland following the Trianon Peace Treaty varied greatly. Due to migration, assimilation and natural death, the number of Hungarians living outside the motherland was rapidly decreasing (Kocsis, K. and TÁtrai, P. 2012): in 1989, the number of Hungarians living outside the borders of current Hungary only reached 2.3 million. A possible initiative to stop this unfavourable process might be the development of ethno-tourism in which Hungarians living in the motherland visit Hungarian territories outside of the political borders to nurture their national identity. As a result of economic growth in the areas involved in such ethno-tourism, due to the spending of visitors and their interest in local heritage, favourable demographic processes might be generated that benefit the Hungarian minorities living there (ILYÉs, Z. 2006).

After the regime change in 1990, the strengthening of national identity and the cohesion of the 'core nation' - the motherland and the Hungarian territories outside the national borders - appeared in a privileged position in the rhetoric of the conservative political parties (A. Gergely, A. 2012; Kocsis, K. 2013). After gaining power in 2010, the current government has realized the potential of young people in reinforcing a sense of national identity that was artificially suppressed during decades of socialism, therefore, they created a programme with the aim to bolster the youngest generation's national identity (PAP, Sz. 2013). The 'Without Borders!' government programme provides financial support for study trips organised by primary and secondary schools to visit Hungarian communities living in the neighbouring countries.

\section{Educational tourism and identity building}

Schools play a role in formal and informal education on the one hand (conveying information, in situ deepening of knowledge, forming students into environment-conscious, responsible citizens), and in socialization (becoming tourists, adapting to foreign environments) on the other hand (Arcodia, C. and Dickson, C. 2009). The gap between theory and practice might be significantly lessened by creating experiences and by experience-oriented teaching outside the classroom (FALK, J. et al. 2012). During study trips organised for peer student groups, the young participants face several challenges and have specific tasks that promote the development of their creativity (Horváth, A. 2015). In secondary and tertiary tourism education, field trips represent an indispensable form of learning and expanding one's practical knowledge (HARris, J. et al. 2012). Trips to foreign countries exponentially increase the function of school trips in the field of education and socialization, and help 
the internationalization of young generations (HuAng, R. 2013). In case the cultural distance is too big between the sending country and the destination, or when students have insufficient knowledge about the destination, participants may find it challenging to adapt to the local circumstances, and the consequent negative experiences may limit the fulfilment of educational objectives (KLOOSTER, E. et al. 2008). However, if the students' opinion is positive, they may soon return to the destination with their relatives or friends, or may repeat the trip later in their lives (FRÄNDBERG, L. 2010).

The protection and presentation of cultural heritage as a tourist attraction play a major role in national identity politics (MorgAN, N. and Pritchard, A. 1998; Pitchford, S. 2008). What stands behind the intensification of daily nationalism is the efforts of offsetting European identity - promoted by the European Union and its predecessors - , embodied in the preservation of national solidarity (PARK, H. 2010). Among the instruments of nation building widely used in Europe one can find the cultivation of mother tongue symbolizing national affiliation, the safeguarding of history and heritage based both on archaeological evidence and legends, the preservation of the iconography of the mutual past as well as the promotion of one's attachment to the national lands (PALMer, C. 1999; HollinsheAd, K. 2009). Identity politics is often discussed in the context of centreperiphery narratives (FonseCA, F. and Ramos, R. 2012). In contrast of the cosmopolitan cities, the rural areas preserving traditions seem to embody national values and represent common roots (Silva, L. and LeaL, J. 2015).

Ethnic tourism has a key place in the successful implementation of national identity politics (YANG, L. and WALL, G. 2009). One of the tools to maintain the connection between the majority nation and national minorities outside the mother country is travelling, which usually takes place under the aegis of cultural and heritage tourism, or visiting tourism of friends and relatives (VFR) (IRImiás, A. 2013). The goals of nationbuilding related to tourism can, of course, be served by other devices as well, such as by nurturing the relations of twin-cities, organizing student exchanges, and offering scholarship programmes (Altinay, L. and Bowen, D. 2006). Throughout the history, governments have used countless peaceful solutions which, symbolically, have contributed to the strengthening of national identity politics (Peters, K. 2011). However, the examination of cross-border school trips with the goal of national identity building represents an under-researched topic in the scientific tourism literature.

As already argued above, including school trips as an active component in an educational programme may have a wide range of objectives, but these are generally connected to the learning process. Possible forms include linking classroom-acquired knowledge with practical experience, e.g. as school excursions to historical or literary sites (AyALON, Y. and SCHNELl, I. 2014), nature immersion programmes (KövecSESNÉ GősI, V. 2009), or reallife foreign language practice (DrozDzEwsKI, D. 2011). Another important educational benefit of travelling stems from the personal growth and attitudinal changes that the participants of field trips or voluntary activities undergo as a consequence of their broadened understanding of the visited destination's realities (OrpetT Long, S. et al. 2010), which may also influence their perceptions of their home environment. And while it may be pointed out that the organisers of trips belonging to the latter category may have underlying soft political motives - such as increasing social sensibility and awareness of the impacts of tourism, supporting critical thinking, or encouraging responsible consumer behaviour during and after the trip (Boyle, A. et al. 2015) - , it is rather uncommon to use educational tourism as a state programme to directly support political objectives.

Although comparisons may be drawn by China's 'red tourism' concept - a nationwide political socialization programme launched in 2004 to promote patriotism and identification with the party-state (Zuo, B. et al. 2017) -, since it also gave priority to political goals over eco- 
nomic considerations, a major difference is that the Chinese project focuses primarily on the supply side, i.e. the identification and development of sites associated with communist heritage and the revolutionary era, was initiated as a domestic tourism programme, and targets the whole population of the country, not only schoolchildren (XU, K. 2015).

\section{Methodology}

A significant part of school trips belong to the sphere of invisible - or hidden or unobserved - tourism (Michalkó, G. and RÁTZ, T. 2013; DE Cantis, S. et al. 2015). With respect of journeys like these, no statistical reporting requirements exist in Hungary. As a consequence, there is no scientific database available on one-day study visits or multi-day school trips using unregistered accommodation.

The 'Without Borders!' programme of the Hungarian government was launched in 2010 and is run by the Human Capacities Grant Management Office (EMET in Hungarian), a background institution of the Ministry of Human Resources. Although EMET has always imposed strict reporting requirements for schools supported by the 'Without Borders!' programme, the conditions have been modified during the project's history. Year 2013/14 was the period when the most detailed trip report had to be submitted - consisting of a completed form together with a travel diary and photo documentation -, so we selected this year's submissions (256 reports in total) for our analysis.

For processing the reports, the method of content analysis was chosen. The website of EMET provides detailed guidance for the participating schools concerning the mandatory content and format of trip reports, enabling us to define the range of available information and to visualise the data structure required for our project. The available information was categorised into three major groups:

- The first group of data represented information about the visited destinations as well as the spatial and temporal characteristics of the journeys: target country, visited settlements, location of accommodation, date of arrival and departure.

- The second group included data on the organisational aspects of the trips: use of tour operator or individual organisation, type of transportation and type of accommodation.

- The third group contained qualitative information on the excursions, such as the type and the characteristics of the programmes, activities organised at each visited site, and the participants' affective and conative experiences during these programmes.

Summarising the information in the first two categories did not mount any particular methodological challenge, since the data were recorded in the required form in the submitted reports. In order to examine in depth to the participants' activities and memorable experiences, inductive content analysis of the submitted travel diaries was employed to identify the key themes. The method was tested by analysing 15 reports, initial codes were classified under activity and experience categories, and themes were developed by expanding, merging or rearranging these initial categories.

The present study is based on the reports written by $7^{\text {th }}$ grade (13-14-year-old) students of Hungarian primary schools who participated in the 'Without Borders!' programme during the 2013/2014 school year. After recording a total number of 256 entries into our database, the first major challenge was to identify and standardize the geographical names given in the forms. All the visited geographical areas are located in the territory of the 'historic Hungary' (as the Kingdom of Hungary before 1920 is often referred to), thus practically all the visited settlements have a traditional Hungarian name widely used in colloquial speech besides their official administrative name in the national language of the given country (e.g. Košice in Slovakia is called Kassa in Hungarian). Although Hungarian speakers living in the territory of Hungary tend to use the Hungarian settlement names almost ex- 
clusively (many of them, especially the children, are not even familiar with the official Romanian, Slovakian, Ukrainian etc. names), in the trip reports, probably due to their official character, mixed usage was found.

Another difficulty was using the shortened, conversational forms of geographical place names instead of the complete forms (for instance, using Gyergyó instead of Gyergyószentmiklós, i.e. Gheorgheni in Romania). In the end, the standardised database contains the (historical) Hungarian as well as the official (administrative) place names of the visited settlements and other geographical entities.

\section{Research findings}

Nation-building strategy: the present-day political setting

In the years leading up to the fall of the socialist system in 1989-1990, a significant aspect of social and political change was the erosion of internationalist ideology and the growing emphasis on national identity (Csepeli, Gr. 1991). Solidarity with the fate of the Hungarian minorities living outside the borders, and strengthening their ties with the motherland formed the ideological cornerstone of both the party that won the first free elections in 1990 (the Hungarian Democratic Forum) and the subsequent right-wing and extreme right parties (BÁRDI, N. 2008). The political elite in cooperation with the World Federation of Hungarians - supported the social and economic progress of the Hungarian minority by various means (Székely, I.G. 2019), and travel has become an integral part of a national reterritorialisation process (FEISCHMIDT, M. 2008). Furthermore, the cooperation between twin cities has gradually become more intensive, and the position of Hungarian-language higher education institutions was strengthened in the minority regions (CSETE, Ö. et al. 2010).

In the meantime, due to the higher living standards, a considerable number of persons of Hungarian origin migrated to Hungary from the neighbouring countries (especially from Romania), and since they could settle down and integrate into the mainstream society easily, their example was followed by subsequent waves of friends and relatives. Since the Hungarian government intended to preserve the minority communities outside the borders (Ablonczy, B. and BÁrdi, N. 2010), in doing so, a so-called 'status act' (Act LXII of 2001 on Hungarians living in neighbouring countries) was accepted in 2001 that granted various benefits and assistance (in e.g. employment, travel, culture, education, social security or health care) for those who declared themselves to be of Hungarian nationality and claimed a so-called 'Hungarian identity card'. Following the accession to the European Union, the transport infrastructure has improved, crossing the borders has become easier, which resulted in the increase of VFR tourism.

In 2003, the World Federation of Hungarians proposed a referendum in order to promote the preferential naturalization of Hungarians without Hungarian citizenship. Although in the referendum held on $5^{\text {th }}$ December 2004 the majority $(51.6 \%)$ of votes were cast in favour of granting dual citizenship to ethnic Hungarians living in the neighbouring countries, only 37.5 per cent of the eligible voters participated, thus the motion failed, since it had to be supported by at least 25 per cent of the electorate. The failure of the referendum and the razor-close results caused shock and disappointment among those who felt responsible for the fate of Hungarian minorities and who stood for the unity of the Hungarian nation. As an aftermath, the psychological state of the Hungarian minorities and their representatives was characterized by desperation and frustration for a long time.

The role of the 'Without Borders!' programme in achieving nation-building goals

The lessons of the failed referendum encouraged decision-makers who came to power in 2010 to use more creative measures to strengthen the sense of national identity in 
the Hungarian society. Since those born after World War 2 were socialized in an educational environment where the 'Trianon issue' was suppressed and the ideology of internationalism dominated, generations grew up feeling disinterested in the fate of Hungarians living outside the borders. Considerable change in this general attitude can most probably be achieved among the youngest age groups, students of primary and secondary schools, by awakening them to the fact that the Hungarian nation is not limited to those who live in Hungary, that there are many communities outside the borders who have preserved their mother tongue, culture and traditions. The most effective way to reach this goal is through personal experiences, so the government decided to support and encourage encounters with Hungarians living in the territory of the former Kingdom of Hungary in the Carpathian Basin (CsEte, Ö. 2011). A journey full of experiences, made together with one's school community, may create long-lasting memories in 13-16 years old youth. If the trip focuses on components of national identity that were previously included in lessons on history, geography, Hungarian literature, arts or music, then the participants are more likely to grow up as conscientious citizens who feel a certain sense of responsibility for the fate of Hungarian minorities outside the borders.

The programme was first announced in 2010, with the objective of giving chance to students of primary ( $7^{\text {th }}$ grade) and secondary ( $3^{\text {rd }}$ grade) schools to visit and to get acquainted with Hungarian communities living in the Carpathian Basin, in the hope that the personal experiences gained during these trips will be shared with the participants' friends and family, thus reducing the general ignorance about Hungarian minorities living outside the borders. (Resolution 101/2010. (X. 21.) of the Hungarian Parliament introduced the Day of National Unity, partly with the objective to establish and strengthen relations between Hungarian and trans border youth.) An additional aim of the initiative was to encourage students to later revisit these or similar areas, or return to these destinations as adults in the future (CsEte, Ö. 2011). The Hungarian government supported the implementation of the programme by funding a certain number of trips each year: 177 excursions were realized in the school year of 2010/2011, and 393 trips in the school year of 2013/2014. The present study is based on the analysis of 256 journeys made by $7^{\text {th }}$ grade (13-year-old) primary school groups in 2013/2014.

The application procedure as a complex orientation tool

The tender dossier of the 'Without Borders!' programme published in 2013 (BGA-13HA-01) specified the countries eligible as destinations for state-supported school trips to Hungarian-inhabited areas. The applicants could choose all the neighbouring countries but Austria as their destination. The targeted age group was 13 years-old. However, no other restrictions were applied: the programme was open to all applicants from private or public schools, from all around the country.

In the school year of 2013/2014, 256 excursions were successfully completed. The participating schools represented 155 towns or villages in Hungary: 14.8 per cent of the participants travelled from Budapest, 18.4 per cent from major cities, 44.2 per cent from towns and 22.6 per cent from villages. Thus, most successful applicants were located in cities or towns $(77.4 \%)$, which generally have more developed educational institutions with more experience or higher capacity in procuring external funding. The analysis of the regional distribution of the participating schools revealed a significant spatial imbalance within the country: while Central Hungary and Transdanubia accounted for 66-66 successful applications respectively, in Eastern Hungary this figure reached 124. This result might be explained, one the one hand, by the relatively unfavourable financial situation of the students in the economically less developed Eastern Hungary region 
(they might have been more motivated to travel abroad within the framework of this programme, due to the lack of alternative options). On the other hand, the geographical location, i.e. the proximity and the accessibility of the potential destination areas might have also influenced the higher involvement of schools located in Eastern Hungary.

An important condition of successful applications was to spend at least one night in the visited country (making the programme relevant from a tourism point of view). In addition, participants were obliged to organise activities that fulfilled at least one of the following criteria: be directly connected to the students' schoolwork (1), or have an educational (2), or cultural focus (3). Furthermore, the government urged participants to take on various optional assignments that could help cultivating the relationship with Hungarian minority communities living abroad. The programme of each group had to be built in three stages: before the trip, the students participated in preparatory, motivational activities, while after the excursion, in the evolution stage they discussed their experiences and shared them with the public (usually on their school's website). The success of an application was significantly influenced by its compliance with the government's objectives of nation-building, i.e. by the extent of planning activities and ceremonies jointly organised with Hungarians living abroad. Although the timing of the trips was not determined by the tender dossier, certain dates strongly associated with Hungarian national identity were preferred, such as the Day of Hungarian Inventors ( $13^{\text {th }}$ June), the Day of Hungarian Science ( $3^{\text {rd }}$ November), the Day of Hungarian Culture (22 ${ }^{\text {nd }}$ January), and the following national holidays or remembrance days endorsed by the state:

- $6^{\text {th }}$ October (Memorial Day for the Martyrs of Arad);

- 23 $3^{\text {rd }}$ October (Memorial Day of the 1956 Revolution);

- $15^{\text {th }}$ March (Memorial Day of the 1848 Revolution);

$-4^{\text {th }}$ June (Day of National Unity).
The spatial and temporal characteristics of the trips

Despite the fact that the tender dossier specified Ukraine as a preferred destination, the detailed analysis of the trips reveals that the majority of the participants avoided Hungary's north-eastern neighbour (which might have been related to the country's political conflict with Russia since March 2014). Romania, on the other hand, proved to be the obvious winner of the 'Without Borders!' programme, as 70 per cent of the participating schools chose the country as their destination. Slovakia was ranked second, with 22.3 per cent of the trips realised in its territory, followed by Serbia $(4.7 \%)$, Slovenia $(2.0 \%)$, Croatia and Ukraine $(0.4-0.4 \%$, respectively). These results are strongly linked to the geographical location of the Hungarian minority communities living outside the borders as well as the historic value and the cultural heritage of the visited regions. Practically all (99.2\%) the analysed trips took place in the second semester of the 2013/2014 school year (8.7\% in March, 16.2\% in April, $44.8 \%$ in May and $30.3 \%$ in June) (Figure 1).

Following the general practice of school excursions, the organizers tended to prefer the month of May as it is near the end of the school year and is likely to provide optimal weather conditions. However, the detailed assessment of the departure dates clearly reflects the nation-building objectives of the trips. 86.5 per cent of the excursions in March were scheduled to leave between $12^{\text {th }}$ and $14^{\text {th }}$ March, providing participants with the opportunity to celebrate the national holiday together with the transborder Hungarian communities. While April and May did not show any temporal concentration, 88.4 per cent of the June trips started between $1^{\text {st }}$ and $4^{\text {th }}$ June, in order to include the Day of National Unity in the programme.

The spatial analysis of the realised trips in two most popular target countries, Romania (Figure 2, a) and Slovakia (Figure 2, b) shows that the range of settlements visited by the participating students is extremely diversified.

Although we can identify certain concentrations in both countries, the high overall 


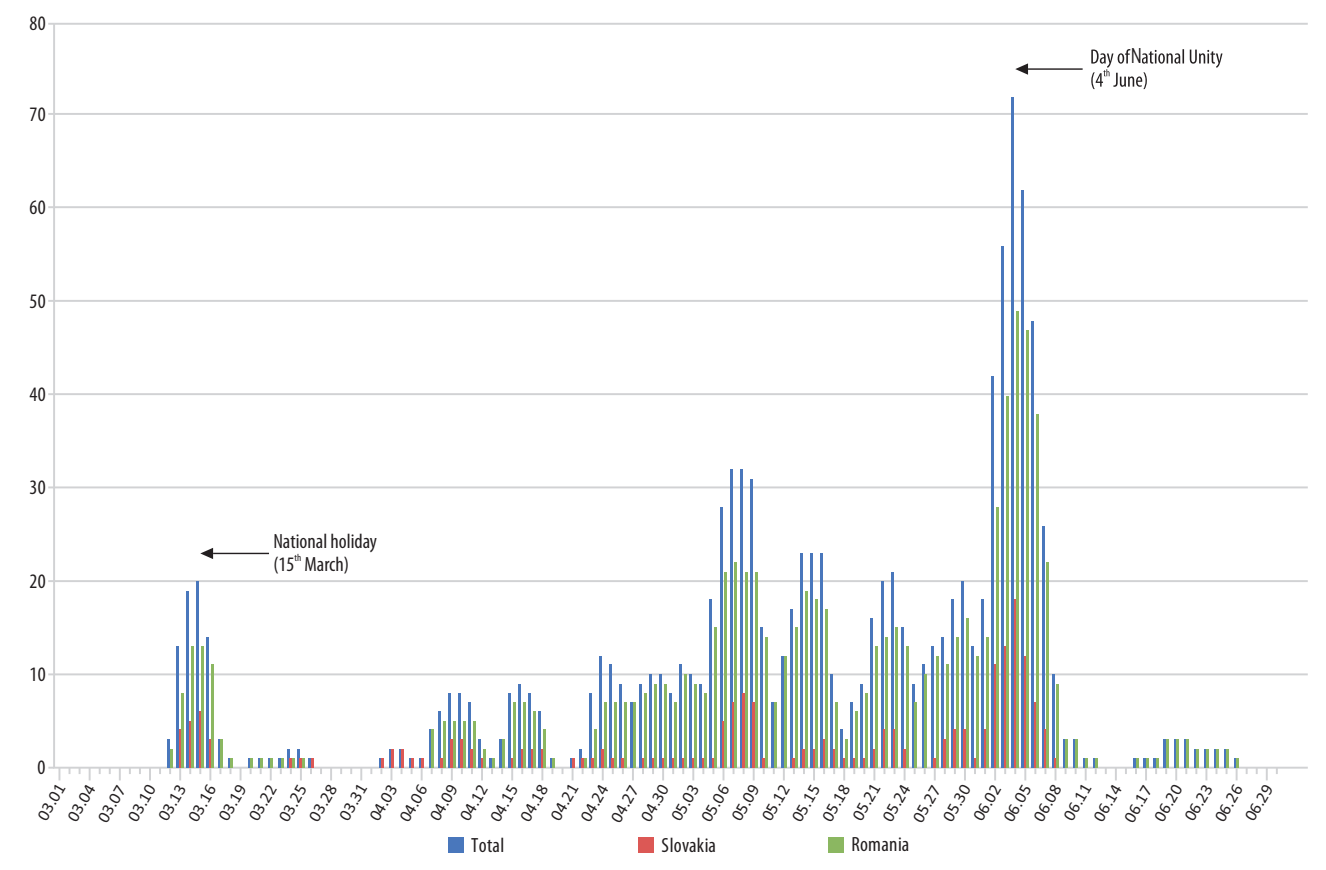

Fig. 1. Temporal characteristics of the analysed trips by calendar date. Source: Edited by the authors based on data collected by EMET.

number of settlements suggests that the groups made a conscious effort to optimally use the available funds and to maximise their experiences. The total number of visited places was 231 in Romania and 115 in Slovakia, while the average number of settlements visited during one trip reached 11 in Romania and 9 in Slovakia. The most popular destinations were major cities and/ or places with significant cultural, historic heritage, such as Oradea/Nagyvárad (visited by $57.2 \%$ of groups travelling to the country), Cluj/Kolozsvár (56.7\%) and Miercurea Ciuc/ Csíkszereda (46.1\%) in Romania; Rožňava/ Rozsnyó (43.9\%), Košice/Kassa (40.4\%) and Bratislava/Pozsony (36.8\%) in Slovakia.

\section{Nation-building tourist programmes and experiences}

The trips taken within the framework of the 'Without Borders!' programme helped strengthen the participants' national identity and contributed to nation-building. The programmes of the excursions generally complied with the project's objectives, and thus included various activities that could increase the value of the applications during the review process. Consequently, the trips followed a predetermined theme, the information provided was linked to the school curriculum, and the teachers used a variety of pedagogical and methodological tools to create experiences and deepen the students' knowledge acquired during their stay abroad. The programmes often included joint activities with local peers as well as initiatives to contribute to the visited community. Sharing celebrations were particularly important elements of certain trips, especially if the dates of the journey coincided with that of a Hungarian national holiday or a remembrance day.

Considering that national identity is rooted, on the one hand, in glorious historic events and personalities as well as in 

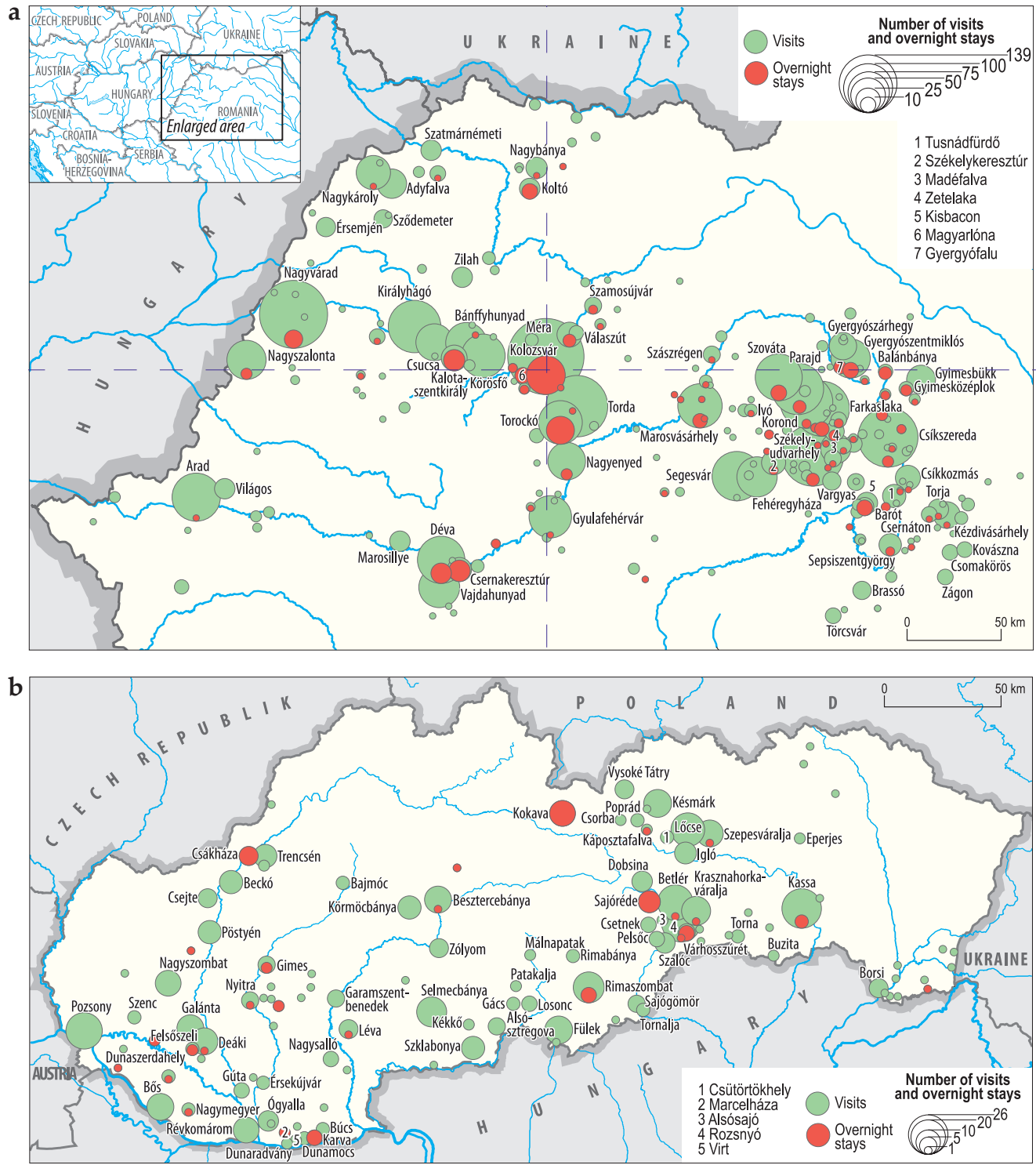

Fig. 2. Romanian (a) and Slovakian (b) destinations of "Without Borders!" school trips, 2013/2014. Source: Edited and designed by the authors based on data collected by EMET.

past traumas and victims and, on the other hand, in nurturing the mother tongue and its dialects, preserving literary monuments and material and immaterial cultural traditions, the thematic design of the trips was also based on these values. Most of the trips had general, broadly defined themes, such as 'Searching for literary and historic facts in Transylvania', 'Cultural-historic adventures in Upper Hungary', and 'The relationship of the natural and the built environment', in order to comply with the requirements and, at the 
same time, preserve a certain degree of flexibility in planning the itinerary and the activities. However, many historic and cultural figures ${ }^{4}$ were also highlighted in the themes: icons whose lives and activities were strongly connected with areas outside the current Hungarian borders. Only a relatively small number of trips had an explicitly national identity-building theme (e.g. 'Joint celebration of national unity - forming a responsible community') or an overtly religious theme (e.g. 'Exemplary co-existence: religious diversity in Transcarpathia').

A classification of the activities described in the trip reports reveals that visiting historic and cultural sites (such as battlefields, birthplaces, cemeteries), sacred places (churches, pilgrimage sites), and the frontiers of historical Hungary were included in almost every excursion (in 255 out of 256). In addition, meeting Hungarian-speaking peers, joining classes in the local schools, sharing meals, participating in cultural events, singing and dancing were also essential elements of the programmes (245/256). Forest hiking, climbing, caving and walking also had an important role (209/256). The participants also tried to find ways to contribute to the local community e.g. by gardening, cleaning or giving gifts (181/256). Doing sports together, especially playing football, was also reported as a popular activity (119/256), however, joint celebrations with trans-border Hungarians were less common (85/256).

\footnotetext{
${ }^{4}$ Among others: Árpád, leader of the Hungarian tribes who conquered the Carpathian Basin in the $9^{\text {th }}$ century and founder of the House of Árpád (895-1301); Saint Ladislaus I of Hungary (1040-1095); János Hunyadi, general and governor, leading commander against the Ottoman army (1407-1456); Matthias I, a renaissance king and a popular hero of Hungarian folk tales (1443-1490); Prince Ferenc Rákóczi II, leader of the 1703-1711 uprising against the Habsburgs (1676-1735); Sándor Petófi, poet, one of the key figures of the 1848-1849 revolution against the Habsburgs, who died in the battle of Sighişoara/ Segesvár (1823-1849); Kálmán Mikszáth, novelist, journalist and politician from Upper Hungary (1847-1910); Áron Tamási, Transylvanian novelist (1897-1966); János Bolyai, mathematician, one of the founders of non-Euclidean geometry (1802-1860).
}

The analysis of the various activities described in the trip reports resulted in the following classification of the core components of the students' memorable experiences: the conscious appreciation of Hungarian identity (A), the excitement of their first trip abroad (B), and the expression of joy of being in a community $(\mathrm{C})$.

A) During the trips, the participants had the opportunity to experience and to consciously reflect on Hungarian identity on many different occasions. Meeting Hungarians living outside the borders and spending time in a Hungarian-speaking environment increased the students' awareness of a greater nationalcultural community. This experience was further reinforced by following the footsteps and encountering the heritage of icons and symbols of Hungarian history and culture 'abroad'.

"It was a great experience that everybody was happy to speak in Hungarian with the children." (HAT/198/2014, trip made from Lepsény to Slovakia.)

B) Most of the participants could also enjoy the excitement of their first tourist experience. Some students had never travelled before, so for them this trip was the first step into the world of tourism, while for many others this was their first international journey, and crossing a border and spending time abroad were the factors that made the excursion truly memorable (during the analysed period, Slovakia and Slovenia were already members of the Schengen Area, but as the analysis of the trip reports indicates, even crossing an 'invisible' border was seen as an adventure by many students).

"For most of us this was the first chance to leave our country, thus crossing the border was a big experience for us." (HAT/103/2014, trip made from Gyomaendrőd to Slovakia.)

C) All the participants could benefit from the joy of community life. Casual encounters outside the classroom, the birth of new friendships or the deepening of existing ones, participating in shared activities, sports, games, meals, social work or giving gifts all contributed to experiencing positive feelings among the students. 
"We were really happy to give gifts to poor children. They were almost in shock of joy and we also felt the same as we saw the light in their eyes." (HAT/27/2014, trip made from Hódmezővásárhely to Romania.)

The three types of experiences strengthened each other in a synergic manner, and together led to reinforcing and intensifying the students' sense of national identity. Sharing them with one's friends and family as well as disseminating them in the form of jointly designed websites also helped in creating long-lasting impressions and memories.

\section{Conclusions}

The end of the socialist regime in 1989-1990 brought about significant changes in the relationships between the mother nation and the Hungarian communities living outside the country's borders. The partly concealed, predominantly culture- and education-oriented dialogue of the previous decades was gradually replaced by a publicly voiced intent of political and legal relations with the mother country. The increasing political engagement of the Hungarian state with the Hungarian communities located beyond the borders, based on the earlier repressed principles of national solidarity and responsibility for the fate of minorities, included supporting ethnic Hungarian political parties in the neighbouring countries, encouraging different levels of autonomy aspirations, assisting the development of higher education institutions and study programmes in Hungarian language, and granting dual citizenship to persons of Hungarian origin.

However, the reception of the government's national policy aiming to create a trans-border sense of cohesion was ambiguous in the mother country, particularly with regard to the preferential granting of citizenship and the subsequent ability of non-residents to vote in the Hungarian elections. It was thus realised that deeper changes in the Hungarian population's inherited attitudes concerning national identity and kinship with communities living beyond the borders could only be achieved gradually, through the education of young generations. Since personal experiences may powerfully affect one's beliefs and attitudes, organised school trips offering personal encounters with Hungarians living outside the country were expected to contribute to a stronger sense of national cohesion and identity among the future generations, enhancing their adherence to the government's political commitment to minorities.

The 'Without Borders!' programme was launched by the Hungarian government to give students of public education a chance to visit Hungarian territories outside the borders within the framework of state-sponsored school trips. The aims of the project were clearly defined: creation and strengthening of national identity in $7^{\text {th }}$ grade primary school students and $3^{\text {rd }}$ grade secondary school students. The programme urged the implementation of activities that directly promoted the awareness of national unity. Most of the participants of the programme chose Romania, more precisely Transylvania as their destination, a region that has the largest population of Hungarian minority and is rich in Hungarian historical and cultural monuments. The settlements visited during the supported school trips were iconic pilgrimage sites of Hungarian culture. The journeys were scheduled throughout the spring semester, with a temporal concentration around politically and culturally important dates such as the $15^{\text {th }}$ March national holiday and the $4^{\text {th }}$ June remembrance day of National Unity. The organised activities and the consequent experiences were considerably pre-determined by the tender dossier, providing the participants with a wide range of opportunities to appreciate national identity. Sharing these experiences with their classmates in a foreign country, and later with their friends, family and the public, contributed to the development of memorable experiences.

Due to the fact that the educational tourism-related activities of adolescents are a 
significantly underrepresented topic in the international literature, the findings of this paper have contributed to filling an existing gap. Although the analysis of trip reports submitted in one single year does not allow us to conclude whether the 'Without Borders!' programme is an effective tool in achieving long term national policy objectives, the results suggest that sharing celebrations of national holidays and memorial days as well as visiting settlements related to iconic figures of Hungarian culture, science and history promoted Hungarian consciousness among the participants. Whether the trips made by the investigated school groups into Hungarian territories outside the borders indeed brought about long term changes in their sense of national identity would require repeat studies focusing on the same sample. However, this would only be possible with the active involvement of both EMET and the students in question. Since the original reporting framework was not created with a follow-up study in mind, a mostly qualitative methodology could be used to compare, on the one hand, the participants' post-trip perceptions on the visit's impact on their national identity with their current attitudes and, on the other hand, their levels of acknowledgement, then and now, of the minority communities' role in the development of Hungarian culture. Complemented by a quantitative component to register any further visits following the first study trip to Hungarian territories outside the borders, a more complex and more accurate picture could be created concerning the effectiveness of national identity development through school trips.

It has been acknowledged since the early ages of scientific tourism research that the tourism system exists in a complex environment and its development is heavily influenced by a wide range of factors including politics. The political environment's impacts may be observed in a variety of shapes including, among others, state ownership of tourism facilities, national development plans and marketing campaigns, visa sys- tems, travel warnings, exchange rate manipulations, or providing holiday opportunities for disadvantaged social groups via social tourism. However, the political environment generally influences the tourism phenomenon in an indirect, regulatory manner, based on predominantly economic considerations, by limiting the state's involvement to providing the necessary framework which, in turn, may affect individuals' travel behaviour. The intention or actual practice of ideological influence on the tourism system is usually found in societies where consumer behaviour is perceived as a moral or political act - such as in the former socialist countries -, and the state considers its mission to educate its citizens to ensure their 'correct' attitudes, behaviour and identity (e.g. in the case of pioneer camps, the World Festivals of Youth and Students organised since 1947, or the current development of 'red tourism' in China).

Generally, participation in tourism is considered a leisure activity as well as a contribution to economic development, and the indicators of success are e.g. guest nights, per capita spending or occupancy rates. Although many countries seem to promote staycations and domestic tourism as a special form of patriotism, these campaigns are also usually built on financial arguments. In the case of the 'Without Borders!' programme however, ideological principles were given priority over economic considerations, and the fact that adolescents, an especially sensible social segment, were involved, made the project particularly relevant for further investigation. As the findings confirmed, the political influence was indeed observed in the preparatory phase of the trips as the itineraries and programmes complied to a high extent with the project's requirements, thus making the feeling of national unity a crucial element of the students' memorable tourist experience.

Acknowledgements: Authors would like to thank the Hungarian Scientific Research Fund (OTKA) for the financial support of this paper. Project number OTKA K 100953. 


\section{REFERENCES}

Ablonczy, B. and BÁrdi, N. 2010. Határon túli magyarok: mérleg, esély, jövő (Hungarians abroad: balance, chance, future). In Határon túli magyarság a 21. században. Ed.: BiтsKEY, B., Budapest, Köztársasági Elnöki Hivatal, 9-32.

Abubakar, A.M., Shneikat, B.H.T. and Oday, A. 2014. Motivational factors for educational tourism: A case study in Northern Cyprus. Tourism Management Perspectives 11. 58-62.

A. Gergely, A. 2012. Hazatérések: nemzeti integráció, önazonosság, identitáspolitika egység és különbség erőterében (Returns: national integration, identity, identity policy in the power of unity and difference). Múltunk 57. (4): 6-19.

Altinay, L. and Bowen, D. 2006. Politics and tourism interface: The case of Cyprus. Annals of Tourism Research 33. (4): 939-956.

Arcodia, C. and Dickson, C. 2009. ITHAS: An experiential education case study in tourism education. Journal of Hospitality and Tourism Education 21. (1): 37-43.

Arcodia, C. and Dickson, C. 2013. Tourism field studies: Experiencing the carnival of Venice. Journal of Hospitality \& Tourism Education 25. (3): 146-155.

Ayalon, Y. and Schnell, I. 2014. German youth educational travel to Israel. Journal of Hospitality \& Tourism Education 26. (4): 188-197.

BÁRDI, N. 2008. A budapesti kormányzatok magyarságpolitikája 1989 után (National politics of Budapest governments after 1989). In Kisebbségi magyar közösségek a 20. században. Eds.: Bárdi, N., Fedinec, Cs. and Szarka, L., Budapest, MTA Nemzeti és Etnikai Kisebbségkutató Intézet - Gondolat Kiadó, 368-375.

Bhandari, K. 2014. Tourism and National IdentityHeritage and Nationhood in Scotland. Clevedon, Channel View Publications.

Boluk, K. and Carnicelli, S. 2015. Activism and critical reflection through experiential learning. Journal of Teaching in Travel \& Tourism 15. (3): 242-251.

Boyle, A., Wilson, E. and Dimmock, K. 2015. Transformative education and sustainable tourism: The influence of a lecturer's worldview. Journal of Teaching in Travel \& Tourism 15. (3): 252-263.

Brien, A. 2011. The Politics of Tourism Development - Booms and Busts in Ireland. London, Palgrave MacMillan.

Burns, P. and Novelli, M. 2007. Tourism and politics: Introduction. In Tourism and Politics - Global Frameworks and Local Realities. Eds.: Bunns, P. and Novelli, M., Oxford, Elsevier, 1-4.

Csepeli, Gy. 1991. Competing patterns of national identity in post-communist Hungary. Media, Culture \& Society 13. (3): 325-339.

Csete, Ö. (ed.) 2011. Határtalanul! - Nemzeti összetartozás az oktatásban (Without borders! - National cohesion in the education). Budapest, A Határon Túli Magyar Oktatásért Apáczai Közalapítvány.
Csete, Ö., PApP, Z.A. and SeténYI, J. 2010. Kárpátmedencei magyar oktatás az ezredfordulón (Hungarian education in the Carpathian Basin at the turn of the millennium). In Határon túli magyarság a 21. században. Ed.: BitskeY, B., Budapest, Köztársasági Elnöki Hivatal, 125-165.

De Cantis, S., Parroco, A.M., Ferrante, M. and VAccina, F. 2015. Unobserved tourism. Annals of Tourism Research 50. 1-18.

DrozDzewsKI, D. 2011. Language tourism in Poland. Tourism Geographies: An International Journal of Tourism Space, Place and Environment 13. (2): 165-186.

Erôss, Á. and TÁtrai, P. 2010. Ethnic features of symbolic appropriation of public space in changing geopolitical frames: the case of Oradea/Nagyvárad. Hungarian Geographical Bulletin 59. (1): 51-68.

Falk, J., Ballantyne, R., Packer, J. and BenckendorfF, P. 2012. Travel and learning: A neglected tourism research area. Annals of Tourism Research 39. (2): 908-927.

Feischmidt, M. 2008. The Hungarian Transylvania: Symbolic reconstruction of lost territories. Hungarian Studies 22. (1-2): 119-133.

FonseCA, F. and Ramos, R. 2012. Heritage tourism in peripheral areas: Development strategies and constraints. Tourism Geographies 14. (3): 467-493.

FRÄNDBERG, L. 2010. Activities and activity patterns involving travel abroad while growing up - The case of young Swedes. Tourism Geographies 12. (1): 110-117.

Gerner, K. 2007. Open wounds? Trianon, the Holocaust, and the Hungarian trauma. In Collective Traumas. Memories of War and Conflict in 20th-Century Europe. Eds.: Mithander, C., Sundholm, J. and Holmgren Troy, M., Brussels, P.I.E. Peter Lang, 79-110.

Harris, J., Lee, S. and Lepr, A. 2012. England, Whales, and Princess Diana - A case study of US students' perceptions of Wales. Journal of Hospitality, Leisure, Sport and Tourism Education 11. (2): 87-92.

Hollinshead, K. 2009. 'Tourism state' cultural production: The re-making of Nova Scotia. Tourism Geographies 11. (4): 526-545.

Horváth, A. 2015. A nemzeti identitásturizmus kreativitásigénye (The need for creativity in national identity tourism). In Kreativitás és innováció a turizmusban. Eds.: Rátz, T. and Michalкó, G., Székesfehérvár-Budapest, Kodolányi János Főiskola, 151-167.

HuANG, R. 2013. International experience and graduate employability: Perceptions of Chinese international students in the UK. Journal of Hospitality, Leisure, Sport and Tourism Education 13. (1): 87-96.

ILYÉs, Z. 2006. Researching and interpreting diaspora. Remarks on social science research into the diaspora communities of the Carpathian Basin. In Perspectives of Diaspora Existence. Hungarian Diasporas in the Carpathian Basin-Historical and Current Contexts of a Specific Diaspora Interpretation and its Aspects of Ethnic 
Minority Protection. Eds.: BALOGH, B. and Ilyés, Z., Budapest, Akadémiai Kiadó, 45-63.

Irimiás, A. 2013. Traveling patterns of Chinese immigrants living in Budapest. Journal of China Tourism Research 9. (2): 180-190.

Juvan, E. and Lesjak, M. 2011. Erasmus exchange program: Opportunities for professional growth or sponsored vacations? Journal of Hospitality $\mathcal{E}$ Tourism Education 23. (2): 23-29.

KASK, S. 2011. Modeling tourist and community decision making. The SAVE model. Annals of Tourism Research 38. (4): 1387-1409.

Klooster, E., Wijk, J., Go, F. and Reком, J. 2008. Educational travel: The overseas internship. Annals of Tourism Research 35. (3): 690-711.

Kocsis, K. 2013. Historical predecessors and current geographical possibilities of ethnic based autonomies in the Carpathian Basin. Hungarian Geographical Bulletin 62. (1): 3-46.

Kocsis, K. and Kocsis-Hodosi, E. 1998. Ethnic Geography of the Hungarian Minorities in the Carpathian Basin. Budapest, Geographical Research Institute, Hungarian Academy of Sciences.

Kocsis, K. and TÁtrai, P. 2012. Changing Ethnic Patterns of the Carpatho-Pannonian Area. Budapest, Geographical Institute, Research Centre of Astronomy and Earth Sciences, Hungarian Academy of Sciences.

KovÁcs, Z. 1989. Border changes and their effect on the structure of Hungarian society. Political Geography Quarterly 8. (1): 79-86.

Kövecsesné Gősı, V. 2009. Az erdei iskola a környezeti nevelés szolgálatában (Forest school for environmental education). Iskolakultúra 19. (5-6): 3-10.

La Placa, V. and Corlyon, J. 2014. Social tourism and organised capitalism: Research, policy and practice. Journal of Policy Research in Tourism, Leisure and Events 6. (1): 66-79.

Liang, K., Caton, K. and Hill, D.J. 2015. Lessons from the Road: Travel, life-wide learning, and higher education. Journal of Teaching in Travel \& Tourism 15. (3): 225-241.

McLaren, L. 2004. Opposition to European integration and fear of loss of national identity: Debunking a basic assumption regarding hostility to the integration project. European Journal of Political Research 43. (6): 895-911.

Michalkó, G. and Rátz, T. 2013. Rejtett dimenziók a Kárpát-medence turizmusában (Hidden dimensions of tourism in the Carpathian Basin). In Kárpát-medence: természet, társadalom, gazdaság. Eds.. Frisnyák, S. and GÁl, A., Nyíregyháza-Szerencs, Nyíregyházi Főiskola, Turizmus és Földrajztudományi Intézet Bocskai István Gimnázium, 463-476.

Morgan, N. and Pritchard, A. 1998. Tourism, Promotion and Power: Creating Images, Creating Identities. Chichester, Wiley

Mosedale, J. (ed.) 2011. Political Economy of Tourism. Oxon, Routledge.
Orpett Long, S., Akande, Y.S. and Purdy, R.W. 2010. Deepening learning and inspiring rigor: Bridging academic and experiential learning using a host country approach to a study tour. Journal of Studies in International Education 14. (1): 89-111.

Palmer, C. 1999. Tourism and the symbols of identity. Tourism Management 20. (3): 313-321.

PAP, Sz. 2013. Encountering the nation beyond borders Hungarian secondary school students, tourism and the micromanagement of nation-building. Unpublished MA thesis. Budapest, Central European University.

PARK, H. 2010. Heritage tourism: Emotional journeys into nationhood. Annals of Tourism Research 37. (1): 116-135.

Pender, L. and Sharpley, R. 2005. Management of Tourism. London, Sage.

Pitchford, S. 2008. Identity Tourism - Imaging and Imagining the Nation. Bingley, Emerald.

Pitman, T., Broomhall, S., McEwan, J. and Majocha, E. 2010. Adult learning in educational tourism. Australian Journal of Adult Learning 50. (2): 219-238.

Peters, K. 2011. Negotiating the place and 'placement' of banal tourist souvenirs in the home. Tourism Geographies 13. (2): 234-256.

Pretes, M. 2003. Tourism and nationalism. Annals of Tourism Research 30. (1): 125-142.

SAnders, D. and Armstrong, E.K. 2008. Understanding tourists' perceptions and experience of a tourism management field trip: The need for a graduated approach. Journal of Hospitality \& Tourism Education 20. (4): 29-37.

SAsse, G. 2008. The politics of EU conditionality: The norm of minority protection during and beyond EU accession. Journal of European Public Policy 15. (6): 842-860.

Silva, L. and Leal, J. 2015. Rural tourism and national identity building in contemporary Europe: Evidence from Portugal. Journal of Rural Studies 38. 109-119.

Székely, I.G. 2019. Mobilizing strategies of Hungarian minority parties in Romania, Serbia and Slovakia. In Populism, Memory and Minority Rights: Central and Eastern European Issues in Global Perspective. Ed.: Bíró, A-M., Leiden, Brill-Nijhof, 145-185.

Tarrant, M.A., Stoner, L., Borrie, W.T., Kyle, G., Moore, R.L. and Moore, A. 2011. Educational travel and global citizenship. Journal of Leisure Research 43 (3): 403-426.

$\mathrm{X}_{\mathrm{U}}, \mathrm{K}$. 2015. Types of red tourists in China: Evidence from Shaoshan. Annals of Tourism Research 51. 51-63.

YANG, L. and WALL, G. 2009. Ethnic tourism: A framework and an application. Tourism Management 30. (4): 559-570.

Young, C. and Light, D. 2001. Place, national identity and post-socialist transformations: An introduction. Political Geography 20. (8): 941-955.

Zuo, B., Gursoy, D. and Wall, G. 2017. Residents' support for red tourism in China: The moderating effect of central government. Annals of Tourism Research 64. 51-63. 
